\title{
Meningkatkan keterampilan praktikum mahasiswa dalam mengelola barang dengan menggunakan sistem inventarisasi barang (SIMVERA)
}

(A Useful Website Based Learning Media in the Covid-19 Era)

\author{
Laurentia Kiki Nefolena, Madziatul Churiyah* \\ Universitas Negeri Malang, Jl. Semarang No. 5 Malang, Jawa Timur, Indonesia \\ *Penulis korespondensi, Surel: madziatul.churiyah.fe@um.ac.id
}

Paper received: 3-3-2021; revised: 24-3-2021; accepted: 28-3-2021

\begin{abstract}
Abstrak
Perkembangan Teknologi Informasi dan Komunikasi (TIK) telah berpengaruh terhadap penggunaan media pembelajaran dimana pendidik dituntut kreatif dalam memanfaatkan teknologi yang berkembang. Oleh karena itu, penelitian ini bertujuan untuk menghasilkan produk media pembelajaran berbasis website untuk meningkatkan keterampilan praktikum mahasiswa. Kini di tengah wabah pandemi covid-19, produk berupa media pembelajaran yang dikembangkan ini dapat menjadi alternatif pilihan dalam pelaksanaan pembelajaran secara daring. Model penelitian dan pengembangan ini menggunakan model Research and Development Borg and Gall yang telah dimodifikasi. Teknik analisis data yang digunakan adalah deskriptif persentase dan Uji Independent Sample t-Test. Hasil penelitian dan pengembangan ini adalah Sistem Inventarisasi Barang (SIMVERA) sebagai media pembelajaran pada mata kuliah manajemen perbekalan dengan menyajikan menumenu terkait kegiatan perbekalan dalam ruang lingkup yang luas meliputi data supplier, data inventaris, data ruangan, data peminjaman, data pengembalian, data pelaporan hingga prosedur penghapusan barang. Selain itu, sistem SIMVERA ini juga dilengkapi dengan QR Code yang dapat diterapkan saat terjadi ketidaksesuaian terhadap barang inventaris. Sistem SIMVERA ini telah dinyatakan sangat valid dan layak digunakan dalam pembelajaran khususnya dalam kegiatan praktikum inventaris barang oleh ahli media, ahli materi, dan 6 mahasiswa uji coba kelompok kecil serta terbukti dapat meningkatkan keterampilan praktikum mahasiswa secara signifikan pada uji coba kelompok besar. Sehingga dapat disimpulkan bahwa Sistem Inventarisasi Barang (SIMVERA) layak dan efektif digunakan sebagai media pembelajaran pada mata kuliah manajemen perbekalan untuk meningkatkan keterampilan praktikum mahasiswa.
\end{abstract}

Kata kunci: sistem inventarisasi barang (SIMVERA); media pembelajaran; website; keterampilan praktikum

\section{Pendahuluan}

Kondisi Pendidikan saat ini telah mengalami perubahan, yang disebabkan oleh adanya coronavirus 2019 (Alpert et al., 2021), (Sharp, 2020). Kemendikbud (2020), melalui Surat Edaran No. 4 Tahun 2020 menjelaskan kebijakan pelaksanaan pembelajaran harus dilaksanakan sesuai dengan protokol kesehatan yang telah ditetapkan oleh pemerintah, salah satunya yaitu melaksanakan pembelajaran dengan metode jarak jauh atau pembelajaran dalam jaringan (Daring). Pembelajaran secara jarak jauh ini akan memfokuskan pembelajaran dari model konvensional menuju pembelajaran modern yang diintegrasikan dengan teknologi informasi dan komunikasi yang dapat membantu menunjang kegiatan pembelajaran sehingga tujuan pembelajaran dapat tercapai meskipun di masa pandemi covid-19 seperti saat ini (Wahid et al., 2020), (Ngafifi, 2014).

Adanya covid-19 ini telah memberikan pengaruh terhadap seluruh tingkatan pendidikan, khususnya lembaga pendidikan formal tingkat perguruan tinggi. Hal ini sesuai 
dengan hasil studi wawancara kepada dosen pengampu mata kuliah manajemen perbekalan Program Studi S1 Pendidikan Administrasi Perkantoran Universitas Negeri Malang, diperoleh informasi terkait kendala atau permasalahan yang terjadi saat pembelajaran masa covid-19 ini, yaitu pada Program Studi S1 Pendidikan Administrasi Perkantoran Universitas Negeri Malang belum tersedia sistem digital atau media pembelajaran yang dapat digunakan sebagai media praktikum/simulasi kegiatan pengelolaan barang inventaris pada mata kuliah manajemen perbekalan, sehingga karena keterbatasan media pembelajaran yang dimiliki maka kegiatan praktikum pengelolaan inventaris barang masih menggunakan media manual berupa tabel inventaris berbasis kertas dengan cakupan keterampilan praktikum masih dalam ruang lingkup yang kecil sehingga keterampilan praktikum mahasiswa masih belum maksimal dan optimal. Ditambah lagi saat pandemi covid-19 yang menerapkan pembelajaran secara jarak jauh tentunya akan sangat sulit melakukan kegiatan praktikum dengan menggunakan media manual sehingga kegiatan praktikum yang dilakukan kurang efektif.

Media pembelajaran memegang peran penting dalam proses pembelajaran yang mana media pembelajaran dapat membantu pendidik untuk mentransfer materi kepada peserta didik (Ramdhani and Muhammadiyah, 2015). Pengembangan media pembelajaran harus mampu menunjang pemahaman mahasiswa dalam mempelajari materi pelajaran, oleh karena itu media pembelajaran harus dibingkai dengan teknologi yang adaptif, praktis dan sesuai dengan kebutuhan sehingga media tersebut dapat membantu meningkatkan proses pembelajaran menjadi efektif dan efisien (Mulwa et al., 2010), (Okedeyi et al., 2015), (Tafonao, 2018). Upaya untuk memberikan akses terhadap mahasiswa dalam melakukan pembelajaran secara jarak jauh dapat dilakukan melalui media website. Website merupakan laman yang dapat memuat informasi berupa teks, gambar, audio bahkan video sehingga media website ini dapat dijadikan inovasi sebagai media pembelajaran yang memiliki kontribusi sangat besar terhadap proses pembelajaran. (Rajesh et al., 2019), (Januarisman and Ghufron, 2016), (Cahyodi and Arifin, 2017), (Sari et al., 2015).

Beberapa penelitian telah mengembangkan sistem informasi manajemen inventaris/aset, yang mana sistem yang dikembangkan tersebut memuat menu-menu mengenai kegiatan perbekalan (Taleizadeh et al., 2020), (Bartoszewicz and Latosiński, 2019), (Cendani et al., 2019), (Dharma et al., 2019), (Rachmawati et al., 2018), (Tejesh and Neeraja, 2018), (Pambudi et al., 2017), (Atieh et al., 2016), (Mirzaei and Seifi, 2015), (Pertiwi et al., 2013). Akan tetapi, pengembangan sistem informasi manajemen inventaris/aset pada penelitian sebelumnya terbatas untuk diterapkan di instansi swasta baik perusahaan atau kantor-kantor tertentu. Berdasarkan pada hal tersebut, peneliti melakukan terobosan untuk mengembangkan sistem inventarisasi barang yang dapat digunakan sebagai media pembelajaran pada mata kuliah manajemen perbekalan khususnya sebagai media praktikum dalam melakukan pengelolaan inventaris barang, yang menyajikan menu-menu terkait kegiatan perbekalan dalam ruang lingkup yang luas meliputi data supplier, data inventaris, data ruangan, data peminjaman, data pengembalian, data pelaporan hingga prosedur penghapusan barang serta dilengkapi dengan QR Code yang dapat di scanning barcode ketika terjadi ketidaksesuaian sewaktu-waktu pada barang inventaris. 


\section{Metode}
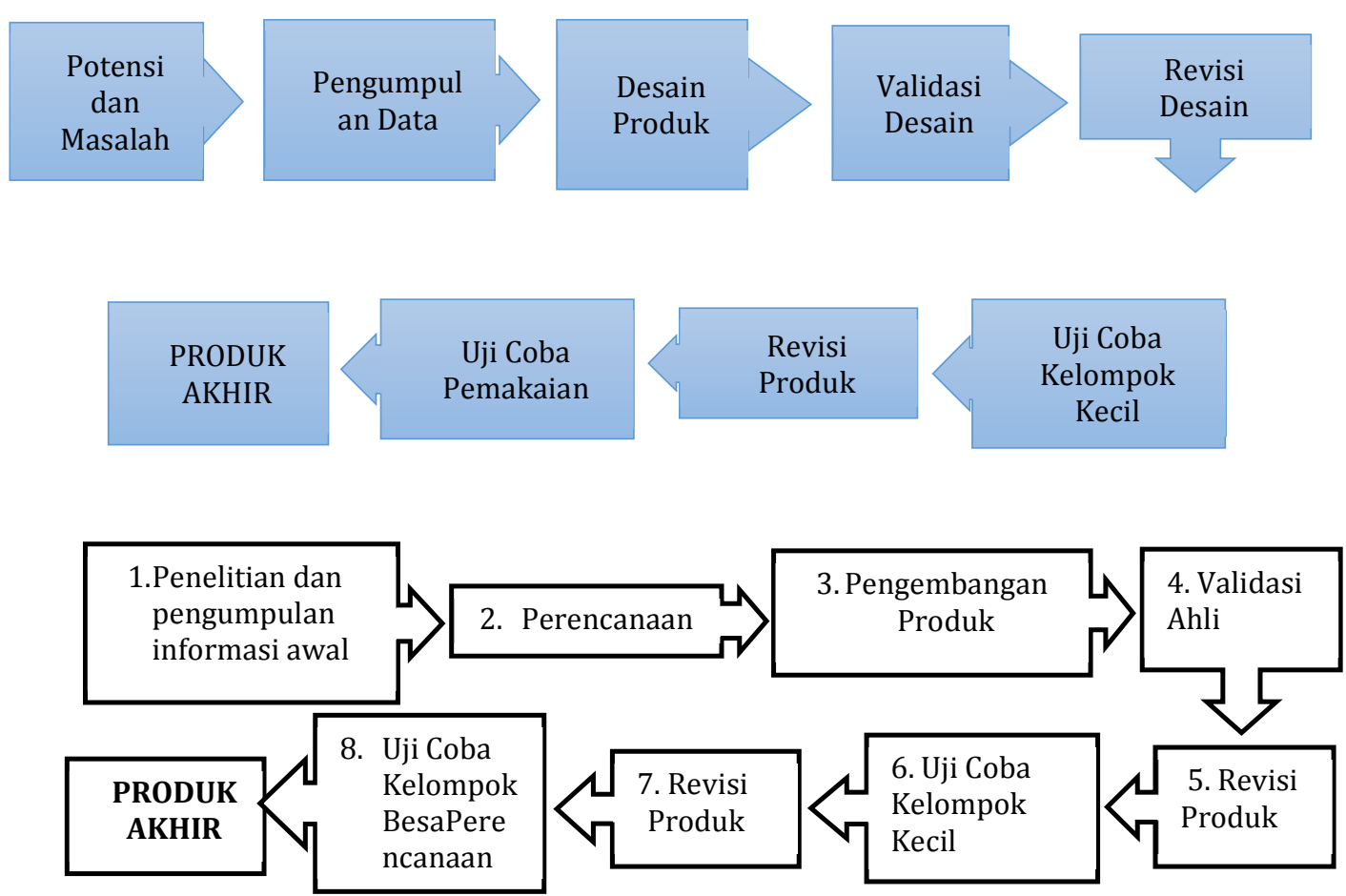

Gambar 1. Langkah-langkah Penelitian dan Pengembangan

Penelitian dan pengembangan ini menggunakan metode Research and Development (R\&D). Sugiyono (2017:298), menyebutkan bahwa terdapat 10 langkah model penelitian dan pengembangan yang dikemukakan oleh Borg and Gall. 10 langkah tersebut dimodifikasi oleh peneliti menjadi 9 langkah yang disesuaikan dengan kebutuhan penelitian dan keadaan di lapangan. Selain itu, tujuan dari penelitian dan pengembangan ini yaitu untuk menghasilkan produk, mengetahui kelayakan produk dari hasil validasi dan mengetahui perbedaan tingkat keterampilan praktikum mahasiswa yang menggunakan dengan yang tidak menggunakan Sistem Inventarisasi Barang (SIMVERA) sebagai media pembelajaran.

Langkah pertama, peneliti mengumpulkan informasi terkait pembelajaran manajemen perbekalan melalui kegiatan wawancara dengan dosen pengampu mata kuliah. Langkah kedua, peneliti mengumpulkan data-data yang diperoleh dari hasil wawancara. Langkah ketiga, peneliti mendesain sistem yang akan dikembangkan dengan mengacu dari data-data yang dikumpulkan dari kegiatan wawancara sebelumnya. Langkah keempat, sistem yang telah dihasilkan diuji kelayakan oleh validator yakni satu validator ahli materi dan satu validator ahli ahli media. Langkah kelima, produk yang telah divalidasi direvisi berdasarkan masukan, kritik dan saran dari validator ahli materi dan ahli media baik secara lisan maupun tulisan sesuai yang tertera dalam angket penilaian. Langkah keenam, produk yang telah direvisi diuji cobakan pada kelompok kecil yang berjumlah 6 mahasiswa, 3 mahasiswa dari offering $\mathrm{N}$ dan 3 mahasiswa lagi dari offering NN. Langkah ketujuh, produk yang telah diuji cobakan pada kelompok kecil direvisi sesuai masukan, kritik dan saran yang diberikan mahasiswa kelompok kecil baik secara lisan maupun tulisan sesuai yang tertera pada angket penilaian. Langkah kedelapan, produk yang telah direvisi kemudian diuji cobakan pada kelompok besar yakni 
pada offering MM yang berjumlah 36 mahasiswa sebagai kelas eksperimen yang menggunakan sIstem SIMVERA, dan pada offering M yang berjumlah 36 mahasiswa sebagai kelas kontrol tanpa menggunakan sIstem SIMVERA. Produk yang telah melewati uji validasi, uji coba kelompok kecil dan uji coba kelompok besar menjadi produk akhir dalam penelitian ini.

Data yang dihasilkan pada penelitian ini meliputi data kuantitatif dan data kualitatif, dimana data kuantitatif diperoleh dari data hasil validasi ahli materi, ahli media dan uji coba kelompok kecil serta data hasil tes psikomotorik mahasiswa. Data hasil validasi ahli materi, ahli media dan uji coba kelompok kecil dianalisis menggunakan metode deskriptif persentase untuk menunjukkan tingkat kesesuaian, kelayakan serta keefektifan sistem sebagai media pembelajaran. Sedangkan hasil tes psikomotorik mahasiswa dianalisis menggunakan uji Independent Sample $t$ Test untuk menunjukkan hasil perbedaan tingkat keterampilan praktikum mahasiswa kelas eksperimen dan kelas kontrol. Sedangkan untuk data kualitatif diperoleh melalui penarikan kesimpulan berdasarkan pendapat secara umum, masukan, kritik dan saran dari ahli materi, ahli media dan 6 mahasiswa uji coba kelompok kecil.

\section{Hasil dan Pembahasan}

Produk yang dihasilkan dalam penelitian dan pengembangan ini adalah berupa Sistem Inventarisasi Barang (SIMVERA) Sebagai Media Pembelajaran Manajemen Perbekalan, sistem SIMVERA ini dirancang berbasis website yang dapat diakses secara online menggunakan komputer, laptop dan dikolaborasikan dengan mobile phone. Selain itu, sistem ini juga dirancang menjadi dua level yakni level pertama sebagai dosen yang khusus diakses untuk dosen pengampu dan level kedua sebagai mahasiswa. Secara garis besar, sistem SIMVERA ini terdiri dari sembilan menu yang dijelaskan pada Gambar 2 di bawah ini: pengoperasian dari sistem SIMVERA yang disajikan dalam bentuk pdf.

PENGATURAN PROFIL. Menu ini berfungsi untuk mengelola profil dari pengguna sistem SIMVERA

DATA PENGGUNA. Menu ini khusus ada pada akun dosen yang berfungsi untuk menambah data pengguna dari sistem SIMVERA

DATA SUPPLIER. Menu ini berfungsi untuk meng-input data-data terkait toko atau perusahaan yang men-supply barang inventaris

DATA INVENTARIS. Menu ini berfungsi untuk meng-input data-data terkait barang

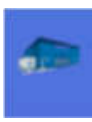

DATA RUANGAN. Menu ini berfungsi untuk meng-input data-data terkait penempatan ruang dari barang inventaris yang dimiliki

DATA PEMINJAMAN. Menu ini berfungsi untuk mengelola data-data terkait peminjaman barang inventaris baik oleh perorangan, unit ataupun lembaga lain 
DATA PENGEMBALIAN. Menu ini berfungsi untuk mengelola data-data pengembalian barang inventaris yang telah dipinjam.

PELAPORAN. Menu ini berisi laporan dari barang inventaris yang telah dikelola, yang dapat langsung dicetak ketika komputer atau laptop tersambung dengan printer

TENTANG. Menu ini berisi informasi pendukung diantaranya yakni informasi mengenai sumber rujukan yang digunakan serta informasi mengenai biodata pengembang sistem.

\section{Gambar 2. Menu-menu yang Tersedia dalam Sistem SIMVERA}

Hasil validasi Sistem Inventarisasi Barang (SIMVERA) oleh ahli materi, ahli media dan mahasiswa uji coba kelompok kecil secara keseluruhan disajikan dalam Tabel 1.1 di bawah ini:

Tabel 1. Data Hasil Validasi Keseluruhan

\begin{tabular}{llll}
\hline No & Validasi & Persentase & Kriteria Validitas \\
\hline 1. & Ahli Materi & $90,67 \%$ & Sangat Sesuai \\
2. & Ahli Media & $97,33 \%$ & Sangat Layak \\
3. & Mahasiswa Uji Coba Kelompok Kecil & $94,44 \%$ & Sangat Efektif \\
& Rata-rata & $94,15 \%$ & Sangat Valid \\
\hline
\end{tabular}

Table used by permission (CNefolena, Laurentia Kiki. 2020. Data hasil validasi keseluruhan.

Berdasarkan Tabel 1 diketahui bahwa rata-rata persentase hasil validasi keseluruhan sebesar 94,15\%, sehingga dapat disimpulkan bahwa Sistem Inventarisasi Barang (SIMVERA) yang dikembangkan oleh peneliti dinyatakan sangat valid dengan kriteria sangat sesuai, sangat layak dan sangat efektif sehingga sistem sangat valid digunakan sebagai media pembelajaran pada mata kuliah manajemen perbekalan khususnya dalam melaksanakan kegiatan praktikum inventarisasi barang. Sedangkan hasil uji Independent Sample t Test pada tingkat keterampilan praktikum mahasiswa pada kelas kontrol dan kelas eksperimen disajikan pada Tabel 2.

Pada Tabel 2 diketahui pada bagian Equal Variances Assumed nilai Sig.(2-tailed) sebesar $0.000<0.05$, sehingga dapat ditarik kesimpulan bahwa terdapat perbedaan keterampilan praktikum yang signifikan antara kelas eksperimen dengan keterampilan praktikum kelas kontrol. Perbedaan keterampilan praktikum yang signifikan ini membuktikan bahwa penggunaan media pembelajaran berupa Sistem Inventarisasi Barang (SIMVERA) yang dikembangkan peneliti efektif dapat meningkatkan keterampilan praktikum mahasiswa. Keterampilan abad 21 yang harus dimiliki individu meliputi 4C yang salah satunya yaitu Creativity and Innovation yakni mampu berkreasi dan berinovasi untuk menyelesaikan permasalahan dengan hal yang baru yakni mahasiswa dapat menyelesaikan kegiatan pengelolaan barang inventaris dengan menggunakan media baru yang berbasis digital sehingga keterampilan praktikum, kemampuan berinovasi penguasaan informasi, media dan teknologi yang ada pada indikator kerangka keterampilan abad 21 dapat tercapai secara maksimal A(Aliftika and Utari 2019), (Nookhong and Wannapiroon, 2015). 
Jurnal Ekonomi, Bisnis dan Pendidikan, 1(3), 2021, 272-282

Tabel 2. Hasil Uji Independent Sample t Test

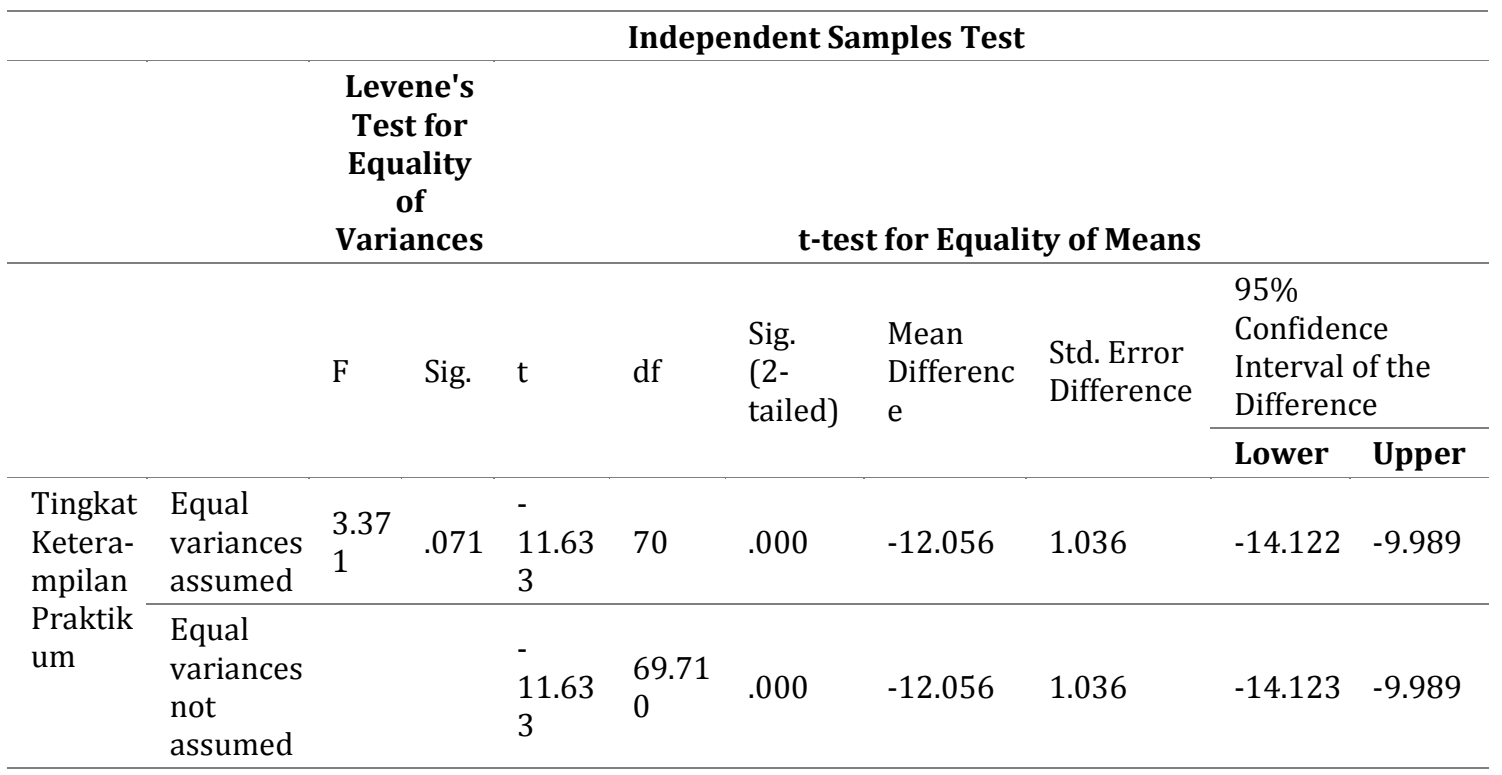

Table used by permission (CNefolena, Laurentia Kiki. 2020. Uji independent samplet-test.

Peningkatan keterampilan praktikum mahasiswa yang signifikan pada penelitian ini disebabkan tersedianya menu-menu yang terkait fungsi perbekalan yang lengkap meliputi pengelolaan data supplier, data inventaris, data ruangan, data peminjaman barang, data pengembalian barang, data pelaporan barang hingga prosedur penghapusan. Selain itu, sistem SIMVERA ini juga dilengkapi dengan fitur QRCode yang dapat mendeteksi deskripsi serta penempatan ruangan dari barang inventaris jika sewaktu-waktu terjadi ketidaksesuaian. Teknologi QR Code dapat memudahkan kepala bagian dalam melakukan monitoring untuk melindungi peralatan dari kerusakan dan kehilangan (Aminah et al., 2020), (Lustig and GozaloDiaz, 2020), (Avidan et al., 2015). Sehingga dalam hal ini mahasiswa dapat lebih terampil dalam melakukan pengelolaan barang dengan cakupan fungsi perbekalan yang lebih luas. Mahasiswa dapat mengerjakan tes psikomotorik dengan melakukan peng-input-an data-data terkait barang inventaris secara mandiri, kapanpun dan dimanapun tanpa harus terikat dengan kegiatan perkuliahan di kelas. Hal ini didukung dengan penelitian-penelitian sebelumnya yang menjelaskan bahwa penggunaan teknologi komputer/media pembelajaran berbasis digital $(e-$ learning/m-learning) signifikan dalam mendukung kemandirian belajar peserta didik (Rahmawati and Mukminan, 2018), (Bandele and Adekunle, 2015), (Nurjanah et al., 2020). Selain itu, desain tampilan sistem SIMVERA dibuat sederhana namun jelas, dengan pemilihan warna yang teduh, icon dan font huruf yang sesuai, bahasa yang mudah dipahami serta kemudahan dalam mengoperasikan sistem SIMVERA ini didapati mampu membuat kelas eksperimen lebih tertarik dan antusias dalam melakukan pengelolaan barang inventaris. Media yang mengkombinasikan teks, grafis, audio, dan animasi yang disajikan dalam berbagai cara yang unik dapat menarik perhatian dan berdampak pada hasil belajar peserta didik (Lee et al., 2014). Tampilan media pembelajaran berupa Sistem Inventarisasi Barang (SIMVERA) dapat dilihat pada Gambar 3 berikut: 


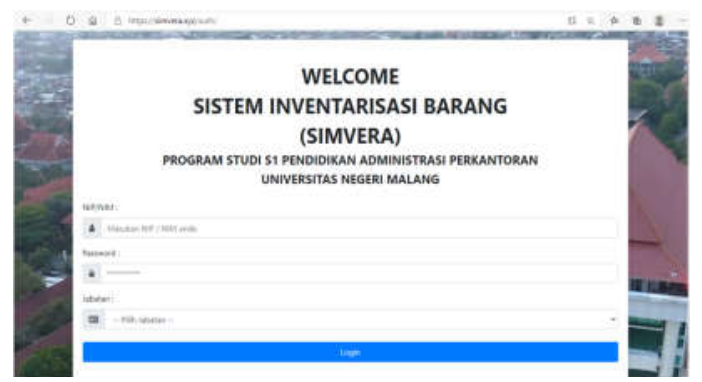

Gambar 3. Tampilan awal sistem SIMVERA

Pada tampilan awal ini pengguna akan diarahkan untuk memasukkan username, password dan level jabatan agar dapat masuk dan mengakses sistem SIMVERA. Adanya fitur log in dengan menyediakan username dan password dapat menjamin keamanan dari data-data informasi yang ada dalam sistem (Wihananto et al., 2018).

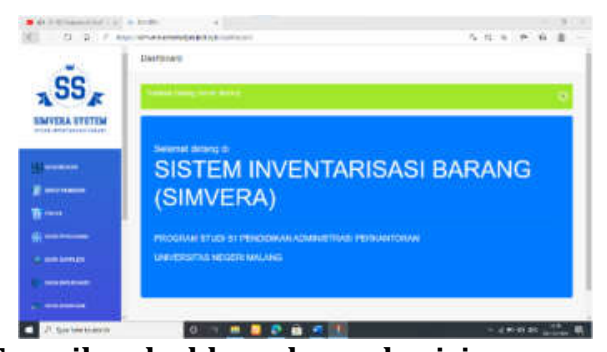

Gambar 4. Tampilan dashboard yang berisi menu-menu dalam SIMVERA

Tampilan dashboard menyajikan tampilan menu-menu yang ada dalam SIMVERA diantaranya Buku panduan, Pengaturan Profil, Data Pengguna (khusus dosen), Data Supplier, Data Inventaris, Data Ruangan, Data Peminjaman, Data Pengembalian, Data Pelaporan dan menu pendukung yaitu menu Tentang.

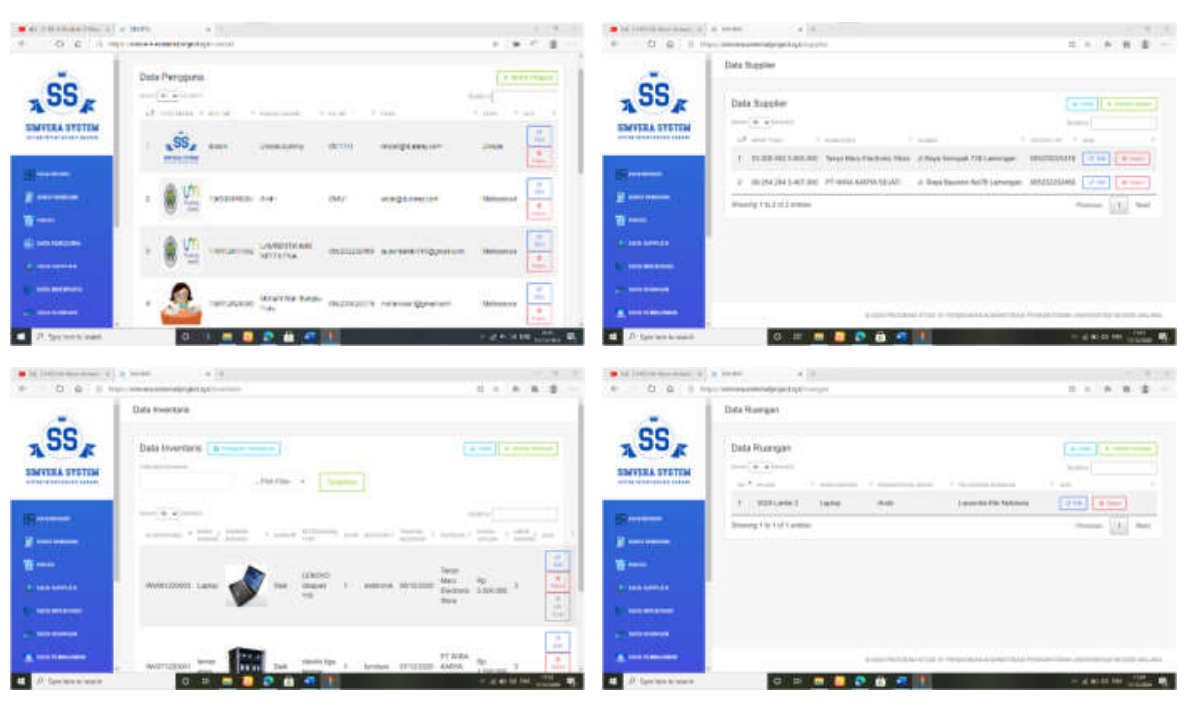




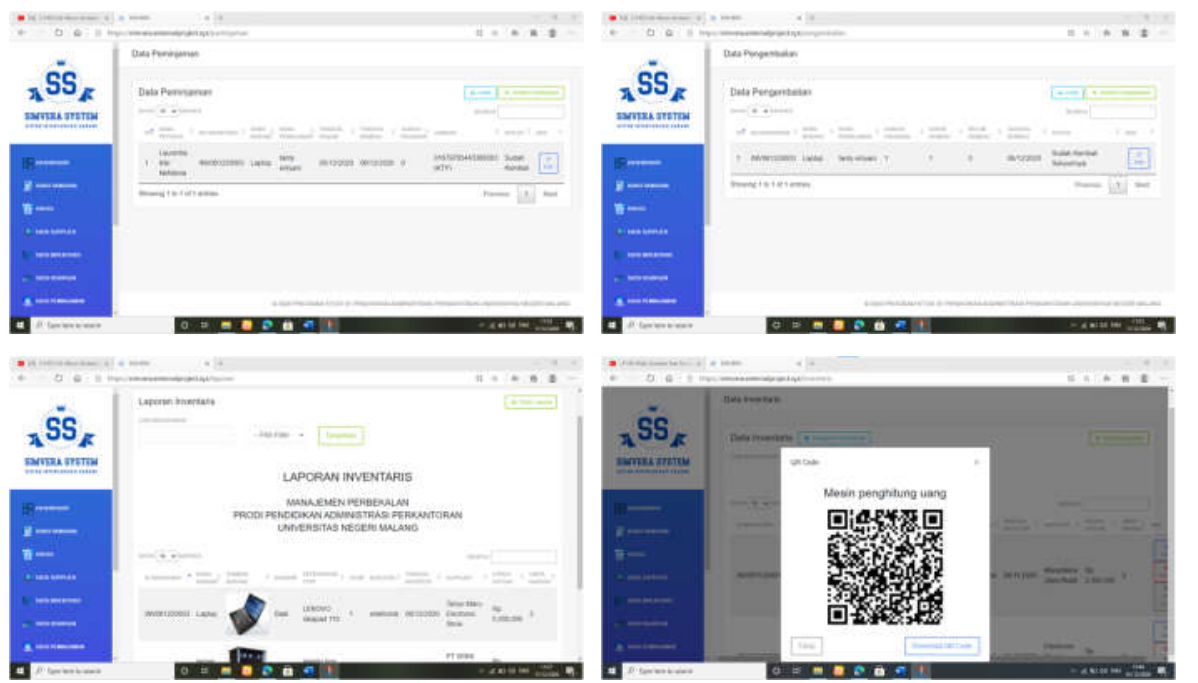

Gambar 5. Tampilan menu-menu utama yang tersedia dalam sistem SIMVERA

Menu yang tersedia dalam sistem SIMVERA sudah mencakup kegiatan dalam fungsi perbekalan yang luas sehingga sistem ini dapat meningkatkan keterampilan praktikum mahasiswa dalam mengelola inventaris barang lebih optimal dan maksimal dengan cakupan ruang lingkup yang luas.

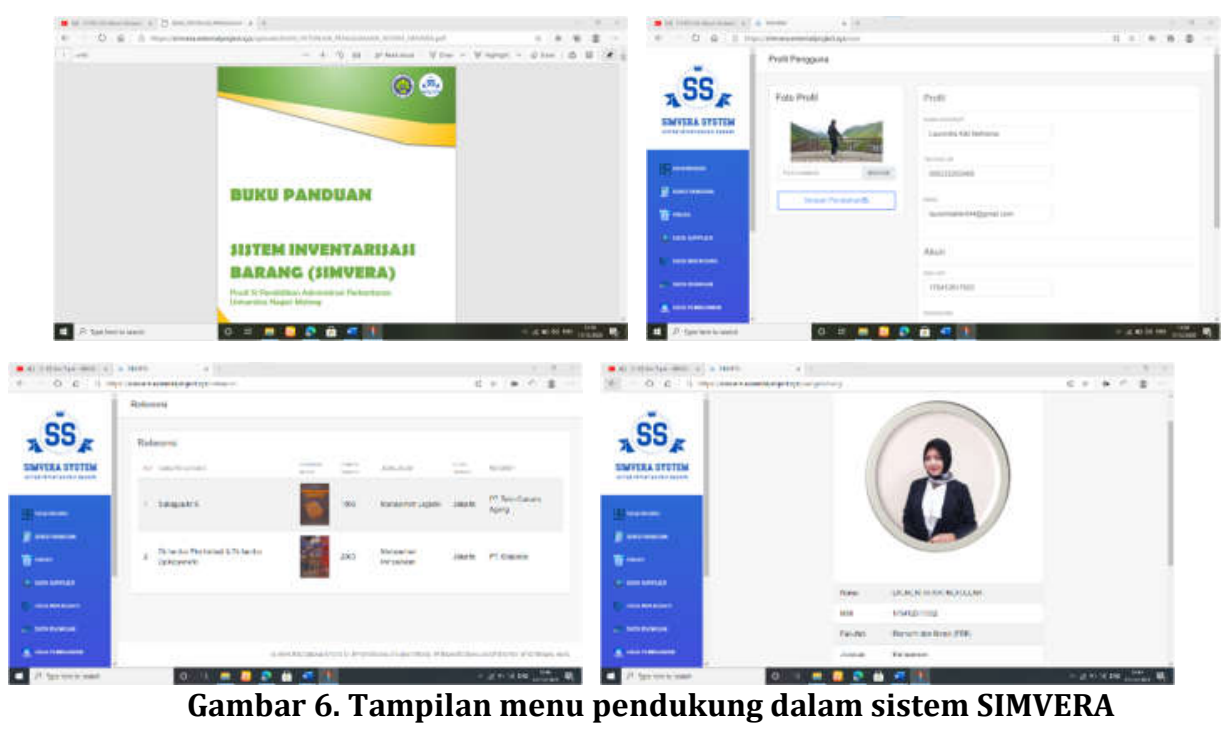

Sistem SIMVERA ini dilengkapi dengan menu pendukung yang meliputi menu buku panduan, menu profil dan menu tentang yang menyediakan informasi-informasi terkait pengembangan sistem SIMVERA.

\section{Simpulan}

Penelitian dan pengembangan ini menghasilkan Sistem Inventarisasi Barang (SIMVERA) sebagai media pembelajaran mata kuliah manajemen perbekalan. Untuk meningkatkan praktikum mahasiswa Program Studi S1 Pendidikan Administrasi Perkantoran Universitas Negeri Malang. Sistem Inventarisasi Barang (SIMVERA) sebagai media pembelajaran ini dapat diakses melalui alamat Url https://simvera.xyz/ 
Sistem Inventarisasi Barang (SIMVERA) pada penelitian ini telah dinyatakan 'Sangat Valid' dan layak digunakan sebagai media pembelajaran pada mata kuliah manajemen perbekalan melalui validasi ahli materi, ahli media serta uji coba kelompok kecil. Selain itu, Sistem Inventarisasi Barang (SIMVERA) sebagai media pembelajaran manajemen perbekalan ini telah terbukti efektif dapat meningkatkan keterampilan praktikum mahasiswa pada uji pemakaian kelompok besar berdasarkan hasil uji Independent Sample t Test. Sistem SIMVERA ini juga memungkinkan pembelajaran secara mandiri, karena dapat diakses kapanpun dan dimanapun ketika tersambung dengan jaringan internet, tanpa harus terikat dengan kegiatan tatap muka di kelas, sehingga sistem SIMVERA ini berguna ketika pembelajaran tidak dapat dilakukan dengan tatap muka seperti saat pandemi Covid-19 ini.

Sistem Inventarisasi Barang (SIMVERA) ini masih terfokus pada pengelolaan barang inventaris yang tidak habis pakai, sehingga diharapkan peneliti selanjutnya dapat mengembangkan sistem untuk pengelolaan barang inventaris yang habis pakai. Selain itu juga diharapkan lebih meningkatkan kreativitas pada desain produk agar lebih menarik dan interaktif.

\section{Ucapan Terima Kasih}

Penulis mengucapkan terimakasih kepada Universitas Negeri Malang khususnya pada Program Studi Pendidikan Administrasi Perkantoran yang telah memfasilitasi dan memberikan izin kepada peneliti untuk melakukan penelitian dan pengembangan ini.

\section{Daftar Rujukan}

Aliftika, O., Utari, S. (2019). Profil Keterampilan Abad 21 Siswa Sma Pada Pembelajaran Project Based Learning (Pjbl) Materi Gerak Lurus. Jurnal Pendidikan Fisika 4, 7. https://doi.org/10.17509/wapfi.v4i2.20178

Alpert, J.B., Young, M.G., Lala, S.V., McGuinness, G., (2020). Medical Student Engagement and Educational Value of a Remote Clinical Radiology Learning Environment: Creation of Virtual Read-Out Sessions in Response to the COVID-19 Pandemic. Academic Radiology 28, 112-118. https://doi.org/10.1016/j.acra.2020.09.011

Aminah, S., Bhaskoro, S. B., \& Sunarya, A. S. (2020). Desain dan Implementasi Aplikasi Inventaris Alat Praktikum Pada Laboratorium Berbasis Android dan QR Code. In Prosiding Seminar Hasil Penelitian dan Pengabdian kepada Masyarakat Unjani Expo (Unex) (Vol. 1, No. 1, pp. 91-95).

Atieh, A. M., Kaylani, H., Al-Abdallat, Y., Qaderi, A., Ghoul, L., Jaradat, L., \& Hdairis, I. (2016). Performance improvement of inventory management system processes by an automated warehouse management system. Procedia Cirp, 41, 568-572. https://doi.org/10.1016/j.procir.2015.12.122

Avidan, A., Weissman, C., Levin, P.D., (2015). Integration of QR codes into an anesthesia information management system for resident case log management. International Journal of Medical Informatics 84, 271-276. https://doi.org/10.1016/j.ijmedinf.2014.12.007

Bandele, S.O., Adekunle, A.S., (2015). Development of C++ Application Program for Solving Quadratic Equation in Elementary School in Nigeria. Journal of Education and Practice 6, 70-77.

Bartoszewicz, A., Latosiński, P., (2019). Sliding mode control of inventory management systems with bounded batch size. Applied Mathematical Modelling 66, 296-304.https://doi.org/10.1016/j.apm.2018.09.010

Cahyodi, S.C., Arifin, R.W.,(2017). Sistem Informasi Point of Sales Berbasis Web Pada Colony Amaranta Bekasi. INFORMATION SYSTEM FOR EDUCATORS AND PROFESSIONALS: Journal of Information System, 1(2), 189-204.

Cendani, T.P., Rusdianto, D.S., Nurwarsito, H., (2019). Pengembangan Sistem Manajemen Inventaris Laboratorium Rumah Sakit Berbasis Web (Studi Kasus: Laboratorium Rumah Sakit Jiwa Prof . Dr . Soerojo Magelang ) Jurnal Pengembangan Teknologi Informasi dan Ilmu Komputer e-ISSN, 2548, 964X.

Dharma, P., Handoyo, S., Wicaksono, S.A., Mursityo, Y.T., 2019. Pengembangan Sistem Informasi Manajemen Inventaris Barang ( Studi pada SMAN 2 Malang) Jurnal Pengembangan Teknologi Informasi dan Ilmu Komputer e-ISSN, 2548, 964X. 
Januarisman, E., Ghufron, A., (2016). Pengembangan Media Pembelajaran Berbasis Web Mata Pelajaran Ilmu Pengetahuan Alam Untuk Siswa Kelas Vii. Jurnal Inovasi Teknologi Pendidikan 3, 166. https://doi.org/10.21831/jitp.v3i2.8019

Lee, Y.H., Hsiao, C., Ho, C.H., (2014). The effects of various multimedia instructional materials on students' learning responses and outcomes: A comparative experimental study. Computers in Human Behavior 40, 119-132. https://doi.org/10.1016/j.chb.2014.07.041

Lustig, L.L., Gozalo-Diaz, D., (2020). Creating QR-coded identification cards using CardExchange for straightforward identification of implant systems. The Journal of Prosthetic Dentistry 124, 623-624. https://doi.org/10.1016/j.prosdent.2020.02.007

Mirzaei, S., Seifi, A., (2015). Considering lost sale in inventory routing problems for perishable goods. Computers and Industrial Engineering 87, 213-227. https://doi.org/10.1016/j.cie.2015.05.010

Mulwa, C., Lawless, S., Sharp, M., Arnedillo-Sanchez, I., Wade, V., n.d. (2010) Adaptive educational hypermedia systems in technology enhanced learning: a literature review. Journal Information technology education 12. https://doi.org///doi.org/10.1145/1867651.1867672

Ngafifi, M., (2014). Kemajuan Teknologi Dan Pola Hidup Manusia Dalam Perspektif Sosial Budaya. Jurnal Pembangunan Pendidikan: Fondasi dan Aplikasi 2, 33-47. https://doi.org/10.21831/jppfa.v2i1.2616

Nookhong, J., Wannapiroon, P., (2015). Development of Collaborative Learning Using Case-based Learning via Cloud Technology and Social Media for Enhancing Problem-solving Skills and ICT Literacy within Undergraduate Students. Procedia - Social and Behavioral Sciences 174, 2096-2101. https://doi.org/10.1016/j.sbspro.2015.02.007

Nurjanah, Latif, B., Yuliardi, R., Tamur, M., (2020). Computer-assisted learning using the Cabri 3D for improving spatial ability and self- regulated learning. Heliyon 6, e05536. https://doi.org/10.1016/j.heliyon.2020.e05536

Okedeyi, A.S., Oginni, A.M., Adegorite, S.O., Saibu, S.O. (2015). The Relevance of Multi Media Skills in Teaching and Learning of Scientific Concepts in Secoundary Schools in Lagos State, Negeria. Journal of Educational and Practice 6, 2222-1735 http://iiste.org/Journals/index.php/JEP

Pambudi, G.S., Sriyanto, S., Arvianto, A., (2017). Rancang Bangun Sistem Informasi Manajemen Aset Berbasis Web Untuk Optimalisasi Penelusuran Aset Di Teknik Industri Undip. J@ti Undip : Jurnal Teknik Industri 11, 187. https://doi.org/10.14710/jati.11.3.187-196

Pertiwi, K., S., K.I., Somantri, M., (2013). Sistem Informasi Manajemen Aset di Fakulttas Teknik Universitas Diponegoro. Transient 2, 39-44.

Rachmawati, R., Arwati, D., Herawati, S.D., Arnan, S.G., (2018). Optimalisasi Penggunaan Teknologi Informasi dalam Penatausahaan Asset/ Barang Milik Daerah. Jurnal ASET (Akuntansi Riset) 10, 9. https://doi.org/10.17509/jaset.v10i2.15159

Rahmawati, E.M., Mukminan, M., (2018). Pengembangang m-learning untuk mendukung kemandirian dan hasil belajar mata pelajaran Geografi. Jurnal Inovasi Teknologi Pendidikan 4, 157. https://doi.org/10.21831/jitp.v4i2.12726

Rajesh, A., Baloul, M.S., Shaikh, N., de Azevedo, R.U., Farley, D.R., (2019). Education website and social media to increase video-based learning of surgical trainees. The Surgeon 17, 381. https://doi.org/10.1016/j.surge.2019.03.004

Ramdhani, M.A., Muhammadiyah, H., (2015). The Criteria of Learning Media Selection for Character Education in Higher Education Proceeding International Conference of Islamic Education: Reforms, Prospects and Challenges Faculty of Tarbiyah and Teaching Training. 174-182.

Sari, A.D., Suryoputro, M.R., Rochman, Y.A., Ulandari, S., Puspawardhani, E.H., (2015). Usability Analysis of Laboratory Website Design to Improve Learning Process. Procedia Manufacturing 3, 5504-5511. https://doi.org/10.1016/j.promfg.2015.07.703

Sharp, K.W., (2020). Educational and Training Lessons from the COVID-19 Pandemic: We Must Prepare for the Next Pandemic. Journal of the American College of Surgeons 231, 626-627. https://doi.org/10.1016/j.jamcollsurg.2020.09.003

Sugiyono. (2017). Metode Penelitian Kuantitatif, Kualitatif, dan R\&D. Bandung: Alfabeta

Tafonao, T., (2018). Peranan Media Pembelajaran Dalam Meningkatkan Minat Belajar Mahasiswa. Jkp 2, 103. https://doi.org/10.32585/jkp.v2i2.113 
Jurnal Ekonomi, Bisnis dan Pendidikan, 1(3), 2021, 272-282

Taleizadeh, A.A., Shokr, I., Konstantaras, I., VafaeiNejad, M., (2020). Stock replenishment policies for a vendormanaged inventory in a retailing system. Journal of Retailing and Consumer Services 55, 102137. https://doi.org/10.1016/j.jretconser.2020.102137

Tejesh, B.S.S., Neeraja, S., (2018). Warehouse inventory management system using IoT and open source framework. Alexandria Engineering Journal 57, 3817-3823. https://doi.org/10.1016/j.aej.2018.02.003

Wahid, R., Pribadi, F., Pribadi, F., Wakas, B.E., Wakas, B.E., (2020). Digital Activism: Covid-19 Effects in Campus Learning. birle, budapest. internation. research. and. critic. in. linguistic. educatie 3, 1336-1342. https://doi.org/10.33258/birle.v3i3.1174

Wihananto, D.S., Kastaman, R., Saukat, M., (2018). Rancang Bangun Sistem Informasi Laboratorium Studi Kasus Di Laboratorium Jasa Uji Ftip - Universitas Padjadjaran. Teknotan 12. https://doi.org/10.24198/jt.vol12n1.1 